\title{
Kapasitas Bioadsorpsi Bakteri Simbiosis Spons Laut Terhadap Kontaminan Logam Berat
}

\section{[Bio-adsorption Capacity of Marine Sponge Symbiosis Bacteria on Heavy Metal Contaminants]}

\author{
Anggi Angela, Ismail Marzuki \\ Program Studi Teknik Kimia, Fakultas Teknik, Universitas Fajar \\ Jl. Prof. Abdurrahman Basalamah No.101, Kota Makassar, 90231 Sulawesi Selatan
}

\begin{abstract}
Heavy metal pollution in the marine environment is quite high. Arsenic and Mercury are two types of dangerous heavy metals because they are toxic and are often found as components of pollution. The research objective was to determine the bio-absorption capacity and efficiency of sponge symbiotic bacteria against arsenic and mercury contaminants. The bio-absorbent material was used by two bacterial isolates, namely Bacillus licheniformis strain ATCC 9789 (BI.6), the sponge symbiont Auletta Sp and Acinetobacter calcoaceticus strain PHCDB14 (Ac.8), the sponge symbiont Callyspongia aerizusa. The isolates were prepared through culture, then incubated $2 \times 24$ hours, suspension BI. 6 and Ac. 8 were made, then adapted for 24 hours. Interaction with As $3+$ and $\mathrm{Hg} 2$ + contaminants with a concentration of $100 \mathrm{ppm}$ in vials with time variations $0,4,8,12,16$ days. The resulting interactions are extracted, concentrated and acidified. The bio-absorption capacity and efficiency were determined based on absorption data using Atomic Absorption Spectrometry (AAS). The average efficiency of the bio-absorption of isolate Bl.6 against $\mathrm{As}^{3+}=99.95 \%, \mathrm{Hg}^{2+}=88.49 \%$, while isolate Ac. 8 against $\mathrm{As}^{3+}=99.95 \%$ and $\mathrm{Hg}^{2+}=85.73 \%$. Based on efficiency data, capacity and bio-absorption power relative to Bl.6 = Ac. 8 against $\mathrm{As}^{3+}$ and BI. $6 \geq$ Ac. 8 contaminants to $\mathrm{Hg}^{2+}$. Isolates BI. 6 and Ac. 8 adsorbed more strongly against $\mathrm{As}^{3+}$ contaminants than $\mathrm{Hg}^{2+}$.
\end{abstract}

Keywords: Bio-adsorption, capacity, heavy metals, symbiont-bacteria, sponge

Abstrak. Pencemaran logam berat pada lingkungan laut cukup tinggi. Arsen dan Merkuri adalah dua jenis logam berat berbahaya karena bersifat toksik dan sering ditemukan sebagai komponen pencemaran. Tujuan penelitian mengetahui kapasitas dan efisiensi bio absorpsi bakteri simbiosis spons terhadap kontaminan Arsen dan Merkuri. Material bio absorben digunakan dua isolat bakteri, yakni Bacillus licheniformis strain ATCC 9789 (BI.6), simbion spons Auletta Sp dan Acinetobacter calcoaceticus strain PHCDB14 (Ac.8), simbion spons Callyspongia aerizusa. Preparasi isolat melalui kultur, lalu diinkubasi 2 × 24 jam, dibuat suspensi BI.6 dan Ac.8, kemudian di adaptasikan 24 jam. Interaksi dengan kontaminan $\mathrm{As}^{3+}$ dan $\mathrm{Hg}^{2+}$ konsentrasi 100 ppm dalam vial dengan variasi waktu 0, 4, 8, 12, 16 hari. Hasil interaksi di ekstraksi, dipekatkan dan diasamkan. Kapasitas dan efisiensi bio absorpsi ditentukan berdasarkan data serapan menggunakan Spektrometri Serapan atom (SSA). Efisiensi rata-rata bio absorpsi isolat Bl.6 terhadap $\mathrm{As}^{3+}=99,95 \%, \mathrm{Hg}^{2+}=88,49 \%$, sedangkan isolat Ac.8 terhadap $\mathrm{As}^{3+}=99,95 \%$ dan $\mathrm{Hg}^{2+}=85$, $73 \%$. Berdasarkan data efisiensi, kapasitas dan daya bio absorpsi relatif BI. $6=$ Ac. 8 terhadap kontaminan As $^{3+}$ dan BI.6 $\geq$ Ac.8 terhadap $\mathrm{Hg}^{2+}$. Isolat BI.6 dan Ac.8 mengadsorpsi lebih kuat terhadap kontaminan As3+ dibandingkan terhadap $\mathrm{Hg}^{2+}$.

Kata kunci: Bioadsorpsi, kapasitas, logam berat, bakteri simbion, spons

Diterima: 15 Januari 2021, Disetujui: 18 Maret 2021

Sitasi: Angela, A., \& Marzuki, I. (2021). Kapasitas Bioadsorpsi Bakteri Simbiosis Spons Laut Terhadap Kontaminan Logam Berat. KOVALEN: Jurnal Riset Kimia, 7(1): 12-22.

\footnotetext{
* Corresponding author

E-mail: ismailmz@unifa.ac.id; ismailmz3773@gmail.com 


\section{LATAR BELAKANG}

Komponen logam berat merupakan salah satu kontaminan pencemaran lingkungan, bukan hanya ditemukan sebagai residu yang tersebar di permukaan tanah, di udara dan bahkan di lautan. Material logam berat, jika tersebar bebas di alam dapat dikategorikan sebagai limbah dan merupakan komponen kontaminan berbahaya golongan bahan berbahaya dan beracun (B3), karena memiliki sifat toksit terhadap lingkungan maupun pada makhluk hidup terutama manusia. Kontaminan logam berat tidak terurai dan dapat terakumulasi dalam tubuh dalam jangka waktu lama. Paparan logam berat konsentrasi rendah dapat memberi efek negatif terhadap tubuh dengan timbulnya berbagai gangguan kesehatan yang dapat terjadi baik akut maupun kronis (Marzuki et al., 2021; Mostafidi et al., 2019; Akinde, 2012)

Sumber kontaminan logam berat berupa residu dapat berasal dari alam akibat bencana alam, seperti gunung meletus, erupsi, tanah longsor, banjir dan bencana alam lainnya, dan berasal dari aktivitas manusia, berupa kegiatan industri pertambangan, industi pengolahan, perbengkelan, transportasi, berbagai jenis pabrik, dan sebagian kecil dari kegiatan rumah tangga. Sifat logam berat yang tidak terurai, menyebabkan terbentuk akumulasi pada media atau objek tertentu. Proses geokimia kontaminan logam berat dapat terjadi dalam jangka waktu tertentu (Marzuki et al., 2021; Muszyńska et al., 2019; Lu et al., 2019). Angin, hujan dan aliran air oleh perbedaan tekanan tekanan akibat ketinggian adalah pencetus siklus geokimia, akhirnya kontaminan logam berat tersebut dapat bermuara di laut. Proses geokimia selanjutnya adalah dinamika yang terjadi di laut, di mana ikan dan berbagai biota lainnya saling berinteraksi, akhirnya ikan dan biota ini dinyatakan terkontaminasi logam berat toksit. Ikan yang tertangkap nelayan, sebagian di konsumsi dan dijual ke masyarakat luas, akibatnya paparan kontaminan logam berat, misalnya timbal, arsen, merkuri, kromium, nikel dan logam berat toksit lainnya tersebar luas di masyarakat. Kondisi ini harus dicegah yang dapat dilakukan sejak dini dari hulu ke hilir dengan menerapkan berbagai metode, salah satunya adalah bioabsorpsi (Orani et al., 2018; Melawaty et al., 2014).

Spons merupakan salah satu biota laut penting, memiliki banyak fungsi dan sifat yang unik karena dapat membentuk simbiosis dengan berbagai mikroorganisme, terutama bakteri. Populasi spons di Indonesia cukup besar, diperkirakan mencapai $65 \%$ dari populasi spons dunia, merupakan salah satu kekayaan alam laut yang harus dipertahankan agar tetap lestari dan menjadi bagian dari ekosistem laut yang bermanfaat dalam menjaga keseimbangan, asimilasi dan kehidupan dalam laut (Marzuki et al., 2020a; 2019a; 2016). Spons salah satu biota laut yang dijadikan barometer biomonitoring dan bioindikator dalam menetapkan status dan tingkat pencemaran logam berat dalam wilayah laut. Pola hidup dan cara menyerap makanan melalui metode filter pedeer, pola pertumbuhan yang sangat lambat, umumnya membentuk simbiosis mutualisma dengan berbagai macam mikroorganisme, memiliki kemampuan menutup permukaan tubuhnya dengan zat lendir berperilaku enzim untuk menangkal predator pengganggu, mampu mengolah sumber makanan dari kompnen hidrokarbon untuk kebutuhan energi dalam mempertahankan hidup (Marzuki, 2020b; 2019b). Zat yang di produksi oleh spons 
sebagai respon atas perubahan habitat lingkungan untuk kelangsungan hidup spons tersebut, diduga kuat berasal dari mikroorganisme yang bersarang dalam tubuh spons. Pengembangan ke arah aplikasi mikrosimbion sebagai biomaterial untuk mereduksi toksisitas logam berat adalah pikiran kritis saintis untuk tujuan pengembangan ilmu pengetahuan dan upaya penyelamatan lingkungan dan memutuskan rantai paparan logam berat terhadap manusia (Medic et al., 2020; Marzuki et al., 2019c; 2019b)

Penelitian tentang aplikasi bakteri simbiosis spons belum banyak di eksplorasi oleh para peneliti dunia, karena ketiadaan bahan spons untuk diteliti, sedangkan di Indonesia terdapat puluhan ribu jenis spons namun, eksplorasi spons baru pada tahap identifikasi dan karakterisasi untuk beberapa jenis dan tujuan spesifik (Marzuki, 2018; De Voogd, 2007). Spons memiliki beberapa karakteristik sebagai bioindikator yang baik dan merupakan alat yang mudah digunakan mencirikan keadaan ekosistem laut. Cara makan spons yang menyerap sari makanan dari lumpur, sehingga dapat terakumulasi berbagai jenis polutan. Komunitas spons bisa hidup di tempat ekstrak terkontaminasi hidrokarbon dan logam berat, mampu menyerap kontaminan logam untuk waktu yang lama, sehingga spons dijadikan indikator logam berat (Gebregewergis, 2020; Venkateswara et al., 2009). Banyaknya spons yang hidup pada terumbu karang menyebabkan morfologi spons bersimbiosis dengan mikroorganisme seperti bakteri. Biomassa spons mencapai $40 \%$, diduga kuat memiliki kemampuan dalam degradasi $\mathrm{PAH}$ dan reduksi toksisitas logam berat dalam metode bioabsorpsi (Marzuki et al., 2019b; 2019c). Penentuan tingkat bioabsorpsi logam berat oleh bakteri simbiosis spons dengan menerapkan persamaan Freundlich, Langmuir, serta Brunauer, Emmet dan Teller (BET), dalam (Marzuki, 2020a; Muszyńska et al., 2019). Penelitian ini merupakan pengembangan dari beberapa penelitian yang telah dilakukan sebelumnya yang fokus untuk mengetahui lebih dalam performa bioabsorpsi bakteri yang di isolasi dari spons laut terhadap logam berat arsen dan merkuri, khususnya pada aspek daya, kapasitas dan efisiensi adsorpsi. Tujuan lainnya adalah menentukan isolat bakteri yang lebih dominan dalam bioabsorpsi kontaminan logam berat khususnya arsen dan merkuri (Marzuki, 2020b; Putri et al, 2014).

\section{METODE PENELITIAN}

\section{Bahan dan Peralatan}

Bahan yang digunakan yaitu dua jenis isolat bakteri, yakni Bacillus licheniformis strain ATCC 9789 (BI.6) dan isolat bakteri Acinetobacter calcoaceticus strain PHCDB14 (Ac.8), $\left[\mathrm{As}_{2} \mathrm{O}_{3} \mathrm{pa}, \mathrm{HgCl}_{2} \mathrm{pa}, \mathrm{HCl} \mathrm{pa}, \mathrm{NaCl} 0,9\right.$ $\%$ fisiologis, $\mathrm{NaOH}$ pa, $\mathrm{KCl}$ pa, (Merck)], Aquabides, Air laut steril, Nutrient agar (NA) pa, kapas, gliserol 20\%, plastik wrap, Aluminium foil, alkohol, kain kasa, Tissu, kertas saring.

Peralatan yang digunakan yaitu: Spektrofotometer serapan atom (AAS) tipe AA24OFS Varians, Shaker incubator, mikroskop, kertas indikator $\mathrm{pH}$ universal, Spektronic-20D+ Shimadzu, $\mathrm{pH}$ meter digital, set gelas, Mikropipet, Ose bulat, Oven Inkubator, LAF, tabung reaksi, Erlenmeyer, handskum, koloni counter dan lampu spiritus. 


\section{Prosedur Penelitian}

\section{Sumber isolat bakteri}

Sampel isolat bakteri Bacillus licheniformis strain ATCC 9789 (BI.6) diisolasi dari spons laut jenis Auletta $\mathrm{Sp}$ dan isolat Acinetobacter calcoaceticus strain PHCDB14 (Ac.8) diisolasi dari spons laut Callyspongia aerizusa. Kedua jenis spons laut tersebut diperoleh dari pantai sekitar Pulau Kodingareng Keke, bagian dari gugusan Kepulauan Spermonde, Wilayah administrasi Pemerintah Kota Makassar. Kedua sampel spons laut diperoleh pada koordinat $S=05^{\circ} 06^{\prime}$ 06.87”, $E=119^{\circ} 17^{\prime} 10.90^{\prime \prime}$, kedalaman 3, 6 m dpl, pH 7 dan salinitas 29, $0 \%$.

\section{Preparasi sampel}

Isolat bakteri Bl.6 dan Ac.8, merupakan simbiosis spons laut. yang digunakan adalah bakteri yang telah dimurnikan, diperoleh dari stok laboratorium, telah di karakterisasi melalui analisis fenotip dan genotip, sehingga spesies bakteri telah diketahui, termasuk strain serta potensi bioabsorpsi terhadap logam berat (Marzuki et al., 2016; Agarwal \& Bagla, 2013; Marzuki et al., 2015). Isolat terpilih diperbanyak dengan metode Kultur pada media NA. Suspensi isolat BI.6 dibuat dengan memasukkan tabung reaksi, ditambahkan 2 $\mathrm{ml} \mathrm{NaCl} 0.9 \%$ fisiologis, kemudian di kocok. Suspensi dimasukkan ke dalam Erlenmeyer dan kemudian di cukupkan volumenya hingga $100 \mathrm{~mL}$ dengan menggunakan $\mathrm{NaCl}$ $0.9 \%$ fisiologis. Selanjutnya disiapkan 10 vial yang telah diberi label sesuai waktu kontak yang direncanakan. Setiap vial masing-masing diisi $10 \mathrm{~mL}$ suspensi bakteri BI.6, di inkubasi selama $2 \times 24$ jam, kecuali vial dengan label nol hari. Prosedur serupa dilakukan terhadap isolat bakteri Ac.8.
Setelah suspensi bakteri di inkubasi untuk adaptasi lingkungan, selanjutnya suspensi tersebut siap di interaksikan dengan kontaminasi logam berat uji arsen dan merkuri (Siahaya et al., 2013).

\section{Pembuatan kurva kalibrasi kontaminan logam berat arsen dan merkuri}

Masing-masing logam uji dibuat larutan standar. Larutan standar $\mathrm{Hg}^{2+}$ dengan deret 0 , 20, 40, 60, 80, dan $100 \mathrm{~mL}$, sedangkan larutan standar $\mathrm{As}^{3+}$ dengan deret $0.00,0.10,0.25$, 0.50, 0.72, dan 1.00. Setiap deret larutan standar diukur nilai absorban menggunakan SSA pada $\lambda_{\text {maks. }}$ Untuk $\mathrm{As}^{3+}=193,7 \mathrm{~nm}$ dan untuk standar $\mathrm{Hg}^{2+}$ diukur pada $\lambda_{\text {maks }}=357,3$ $\mathrm{nm}$. Deretan absorban hasil pengukuran masing-masing logam diplot ke dalam sumbu Chartesian setelah sebelumnya dihitung nilai "a" dan nilai "b" sehingga diperoleh persamaan regresi:

$$
y=a X \pm b
$$

Nilai $R^{2}$ juga dapat ditentukan untuk memastikan data hasil pengukuran dengan tingkat validitas tinggi apabila $R$ mendekati nilai 1, 00. Hasil perhitungan persamaan regresi masing-masing logam kemudian digunakan untuk menghitung konsentrasi logam uji yang diadsorpsi oleh sampel isolat BI.6 dan Ac.8, bakteri simbion spons laut dengan memasukkan nilai absorban hasil pengukuran AAS berdasarkan waktu kontak antara suspensi isolat bakteri terhadap logam berat uji $\mathrm{As}^{3+}$ dan $\mathrm{Hg}^{2+}$ (Wibowo et al., 2019).

\section{Interaksi dan proses bioadsorpsi}

Disiapkan larutan logam uji masingmasing dengan konsentrasi $250 \mathrm{mg} / \mathrm{L}$ yang selanjutnya di sebut sebagai limbah terkontaminasi Arsen dan Merkuri. Limbah terkontaminasi arsen sebanyak $5 \mathrm{~mL}$ di 
masukkan dalam masing-masing vial yang berisi suspensi BI.6 dan juga ke dalam vial yang berisi Ac.8. Prosedur interaksi yang sama juga dilakukan dengan menggunakan limbah terkontaminasi merkuri, sehingga diperoleh 20 vial berisi masing-masing $15 \mathrm{~mL}$ suspensi dan kontaminan limbah logam berat. Semua vial di Shaker menggunakan Shaker inkubator pada putaran 100 rpm, kecuali vial dengan label 0 hari langsung disaring. Vial yang telah mencapai waktu kontak 4 hari di pisahkan dan disaring menggunakan kertas saring Whatman no. 41, Proses penyaringan dilakukan untuk semua vial sesuai waktu kontak. Filtrat yang diperoleh di asamkan, untuk kontaminan mengandung Arsen pada pH 5 sedangkan filtrat mengandung merkuri pada $\mathrm{pH} 6$. Masing-masing filtrat sesuai label diukur absorbannya menggunakan AAS. Adsorban yang terukur selanjutnya dihitung konsentrasi serapan sebagai konsentrasi yang tidak teradsorpsi oleh isolat bakteri dengan memplot absorban hasil pengukuran dalam persamaan linier (Supriyantini et al., 2017; Marzuki et al., 2019a).

Penentuan daya bioabsorpsi isolat bakteri dihitung dari selisih konsentrasi awal (nol hari) kontak terhadap konsentrasi akhir pada waktu kontak tertentu, sedangkan kekuatan bioabsorpsi antara kedua jenis isolat BI.6 dan Ac.8 ditentukan dengan melihat tren bioabsorpsi dalam grafik. Kapasitas bio-adsorpsi dapat dihitung menggunakan rumus:

$$
Q=\frac{C 1-C 2}{C 1} \times V
$$

Presentase bioabsorpsi atau efisiensi absorpsi dapat dihitung dengan menggunakan rumus:

$$
\% E=\frac{C 1-C 2}{C 1} \times 100
$$

Keterangan:

$Q=$ Kapasitas Absorpsi perbobot molekul (mg/g);

$\mathrm{C} 1=$ Konsentrasi awal larutan $(\mathrm{mg} / \mathrm{L})$;

$\mathrm{C} 2=$ Konsentrasi akhir larutan $(\mathrm{mh} / \mathrm{L})$;

$\mathrm{m}=$ Massa Adsorban (g);

$\mathrm{V}=$ Volume larutan (L); dan

$\% \mathrm{E}=$ Efisiensi Absorpsi.

\section{HASIL DAN PEMBAHASAN}

Kurva kalibrasi dibuat berdasarkan data serapan deret masing-masing logam yang diukur menggunakan SSA pada $\lambda_{\text {maks. }}$ Logam yang diukur. Data di plot dalam sumbu Chartesian dan diperoleh nilai "a" dan "b" dan persamaan regresi serta nilai $\mathrm{R}^{2}$.

Penanganan logam berat dapat dilakukan dengan beberapa metode salah satu diantaranya adalah memanfaatkan bahan alam misalnya bakteri, jamur atau fungi dalam metode bioremediasi bertujuan untuk mengabsorpsi konsentrasi ion logam sehingga daya racun dari logam tersebut dapat diminimalkan.

Beberapa jenis logam berat dapat diabsorpsi dengan menggunakan mikroorganisme (bakteri) diantaranya logam Kromium $(\mathrm{Cr})$, Timbal $(\mathrm{Pb})$, Arsen (As), Nikel (Ni), Kobalt (Co), Merkuri $(\mathrm{Hg})$ dan logam berat lainnya (Marzuki, 2020b; 2019a; 2019c; Mardekawati, et al., 2004). Riset yang telah dilakukan terkait dengan remediasi toksisitas logam berat $\mathrm{Pb}, \mathrm{Hg}$ dan $\mathrm{As}$ menggunakan mikroorganisme yang di isolasi dari spons laut. Data hasil riset yang dilakukan dengan melihat beberapa parameter diantaranya deret standar logam berat uji. 
Tabel 1. Performa bioabsorpsi isolat bakteri BI.6 dan Ac. 8 terhadap logam berat uji berdasarkan waktu kontak

\begin{tabular}{|c|c|c|c|c|c|}
\hline $\begin{array}{l}\text { Jenis } \\
\text { Isolat }\end{array}$ & $\begin{array}{c}\text { Waktu } \\
\text { Kontak } \\
\text { (Hari) }\end{array}$ & $\begin{array}{c}\text { Absorban } \\
\mathrm{As}^{3+}\end{array}$ & $\begin{array}{c}\text { Kons. As }{ }^{3+} \\
(\mathrm{mg} / \mathrm{L})\end{array}$ & $\begin{array}{c}\text { Absor-ban } \\
\mathrm{Hg}^{2+}\end{array}$ & $\begin{array}{c}\text { Kons. } \mathrm{Hg}^{2+} \\
(\mathrm{mg} / \mathrm{L})\end{array}$ \\
\hline \multirow{5}{*}{ BI.6 } & 0 & 447,400 & 243,107 & 3395,387 & 237,234 \\
\hline & 4 & 21,971 & 11,971 & 54,614 & 32,770 \\
\hline & 8 & 2,173 & 1,215 & 50,722 & 30,435 \\
\hline & 12 & 1,446 & 0,820 & 48,942 & 29,367 \\
\hline & 16 & 0,155 & 0,119 & 45,616 & 27,371 \\
\hline \multirow{5}{*}{ Ac. 8} & 0 & 33,982 & 243,107 & 203,252 & 0,000 \\
\hline & 4 & 21,858 & 11,910 & 61,516 & 36,911 \\
\hline & 8 & 3,362 & 1,861 & 56,966 & 34,181 \\
\hline & 12 & 1,442 & 0,818 & 56,634 & 33,982 \\
\hline & 16 & 0,152 & 0,117 & 56,402 & 33,843 \\
\hline
\end{tabular}

Tabel 1 menunjukkan bahwa tingkat bioabsorpsi isolat BI.6 dan Ac.8 terhadap ion $\mathrm{As}^{3+}$ dan $\mathrm{Hg}^{2+}$, menunjukkan hasil yang relatif sama pada masa kontak $4-16$ hari, namun secara spesifik terlihat bahwa nilai adsorpsi ion $\mathrm{As}^{3+}$ lebih besar jika dibandingkan dengan nilai adsorpsi $\mathrm{Hg}^{2+}$, ini berarti bahwa kinerja bioabsorpsi Bl.6 dan Ac.8 terhadap ion $\mathrm{As}^{3+}$ lebih besar dibandingkan terhadap ion $\mathrm{Hg}^{2+}$. Ada dua faktor yang mempengaruhi daya bioabsorpsi suatu adsorben atau isolat bakter terhadap ion logam, yakni faktor karakteristik bakteri sebagai adsorben dan kondisi ion logam sebagai adsorbat. Beberapa faktor yang berpengaruh pada kemampuan bakteri dalam mengadsorpsi kontaminan logam berat diantaranya: kecukupan nutrisi, ketersediaan oksigen, dan kemampuan bakteri beradaptasi dengan lingkungan toksit terkontaminasi logam berat (Lajayer et al.,2019; Novitriani \& Kusmiati, 2015). Tinjauan aspek internal ion logam sebagai adsorbat yang mempengaruhi mudah tidaknya teradsorpsi oleh adsorben bakteri tergantung pada karakteristik ion logam, diantaranya nilai jari-jari ion, afinitas, nilai muatan kation dan elektronegativitas ion logam. Muatan kation $\mathrm{As}^{3+}$ lebih besar disbanding $\mathrm{Hg}^{2+}$, sehingga $\mathrm{As}^{3+}$ memiliki kecenderungan lebih mudah terjerap oleh adsorben bakteri (BI.6 dan Ac.8), demikian pula pada aspek afinitas elektron $\mathrm{As}^{3+}$ lebih kecil dibandingkan $\mathrm{Hg}^{2+}$, termasuk ektronegativitas $\mathrm{As}^{3+}$ lebih besar dibandingkan $\mathrm{Hg}^{2+}$, sehingga ion arsen memiliki kecenderungan lebih mudah terjerap baik oleh isolat bakteri BI.6 maupun oleh Ac.8 dibandingkan ion merkuri. Hasil ini sesuai dengan penelitian sebelumnya yang telah dilakukan terhadap logam Kromium ( $\mathrm{Cr}$ ) (Marzuki et al., 2019b) dan logam Kadmium (Cd), Timbal ( $\mathrm{Pb})$, Mangan (Mg), Nikel (Ni), Tembaga ( $\mathrm{Cu}$ ), Besi $(\mathrm{Fe})$ dan logam lainnya, baik dalam metode adsorpsi maupun dalam metode fitoremediasi (Hidayah et al., 2014; Suryati \& Priyanto, 2003).

Daya bioabsorpsi isolat BI.6 terhadap ion $\mathrm{As}^{3+}$ lebih tinggi dibandingkan terhadap ion $\mathrm{Hg}^{2+}$. Hal yang sama juga ditunjukkan isolat Ac.8 relatif memiliki daya bioabsorpsi lebih tinggi terhadap ion $\mathrm{As}^{3+}$ dibandingkan terhadap ion $\mathrm{Hg}^{2+}$.

Perbandingan daya bioabsorpsi isolat Bl.6 dengan Ac. 8 terhadap ion $\mathrm{As}^{3+}$ tampak relatif sesuai, namun jika membandingkan daya bioabsorpsi isolat Bl.6 dengan Ac.8 terhadap ion $\mathrm{Hg}^{2+}$ terlihat bahwa isolat BI.6 
lebih dominan dibandingkan isolat Ac.8. Gambar 1.a dan 1.b di atas memperlihatkan bahwa pengaruh sifat periodik ion berpengaruh pada mudah tidaknya logam

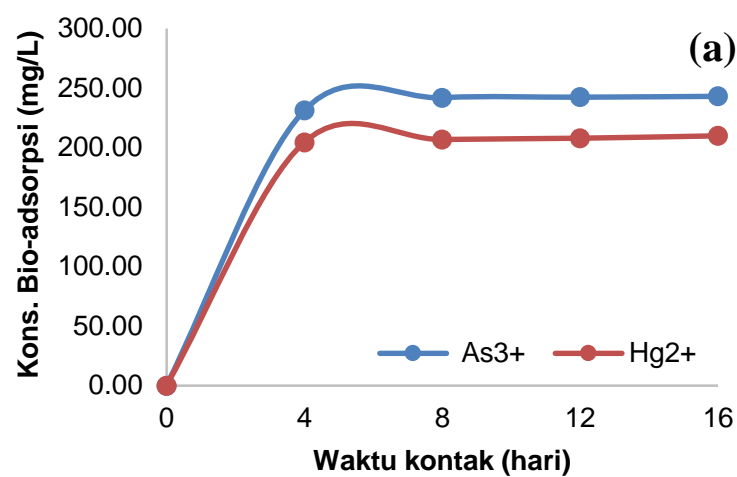

tersebut terjerap oleh suatu adsorpben (Sobrinho et al., 2020).

Gambar 1. (a) Bioadsorpsi isolat Bl.6 terhadap Ion $\mathrm{As}^{3+}$ dan $\mathrm{Hg}^{2+}$ dan (b) Bioadsorpsi isolat Ac.8 terhadap ion $\mathrm{As}^{3+}$ dan $\mathrm{Hg}^{2+}$

Gambar 2.a dan 2.b, menujukkan perbedaan efisiensi bioabsorpsi isolat bakteri BI.6 dan Ac.8 terhadap logam berat. Isolat bakteri Bl.6 maupun Ac.8 memperlihatkan efisiensi bioabsorpsi terhadap $\mathrm{As}^{3+}$ jauh lebih tinggi dibandingkan terhadap $\mathrm{Hg}^{2+}$. Hasil ini

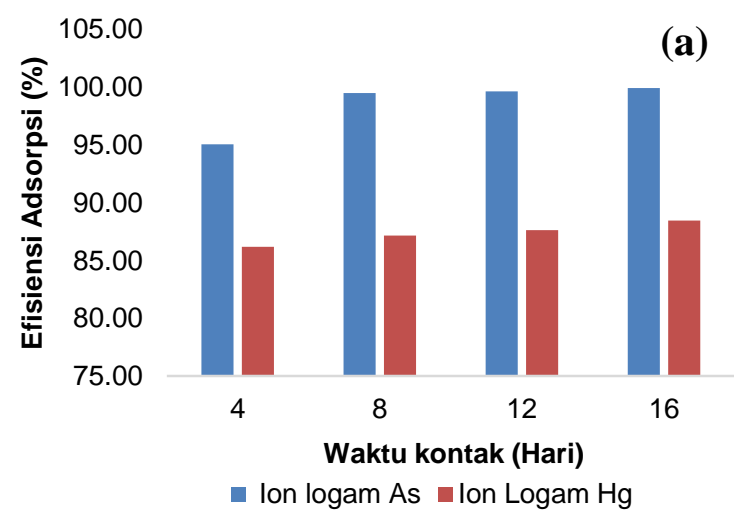

Gambar 2. Efisiensi bioabsorpsi isolat BI.6 (a) dan isolat Ac.8 (b) terhadap ion $\mathrm{As}^{3+}$ dan $\mathrm{Hg}^{2+}$.

Perbedaan tingkat bioabsorpsi suatu mikro organisme terhadap suatu kontaminan logam berat, khususnya bakteri atau mikroorganisme yang membentuk simbiosis dengan spons khususnya jenis BI.6 dan Ac.8, juga ditentukan oleh faktor yang berkaitan dengan jenis logam berat, misalnya faktor substrak logam berat seperti nilai afinitas elektron, ukuran ion, tingkat oksidasi, jari-jari menunjukkan bahwa perbedaan sifat dan karakteristik antara ion logam $\mathrm{As}^{3+}$ dengan $\mathrm{Hg}^{2+}$ berpengaruh dalam kemudahan terjadinya penjerapan absorben bakteri BI.6 dan Ac.8.

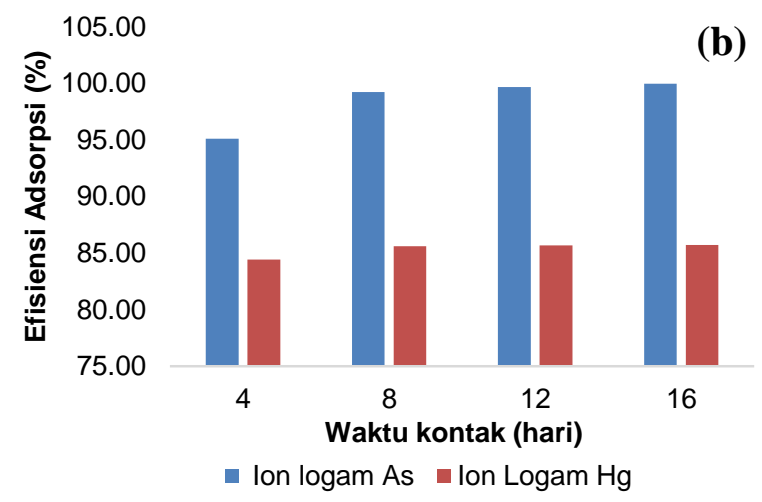

ion, elektronegativitas dan tingkat toksisitas ion logam berat, sedangkan faktor mikro simbiosis misalnya jumlah sel, jenis spons, sumber mikro simbiosis, kemampuan sel beradaptasi dan ukuran sel. Tingkat absorpsi juga dipengaruhi oleh kondisi lingkungan absorpsi seperti $\mathrm{pH}$ media, suhu, ada tidaknya nutrien, agitasi, dan waktu interaksi (Marzuki et al., 2019a; 2019c). 
Kapasitas bioabsorpsi isolat bakteri Bl.6 dan Ac.8 relatif sama dengan efisiensi dan data adsorpsi yang dipengaruhi oleh beberapa faktor baik pada sisi sifat dan karakteristik mikro organisme (bakteri) yang digunakan

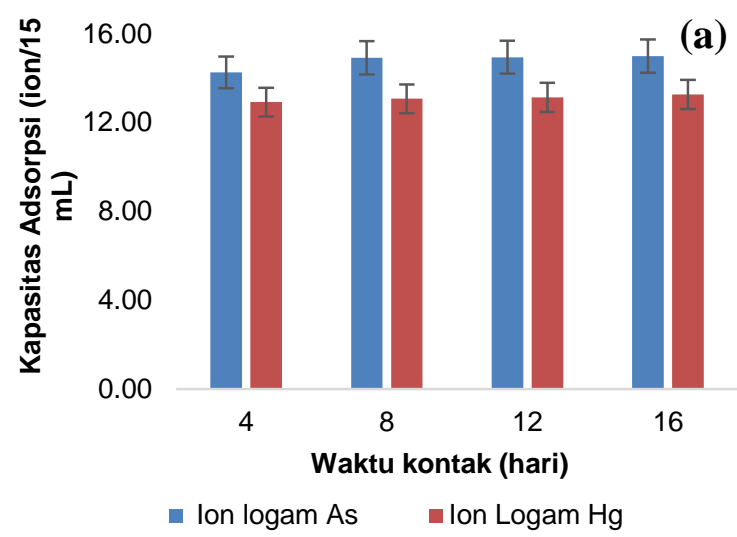

maupun pada aspek sifat periodik dan karakteristik kontaminan logam sebagai material adsorbat atau komponen yang terjerap, sebagaimana yang tampak pada Gambar 3.a.

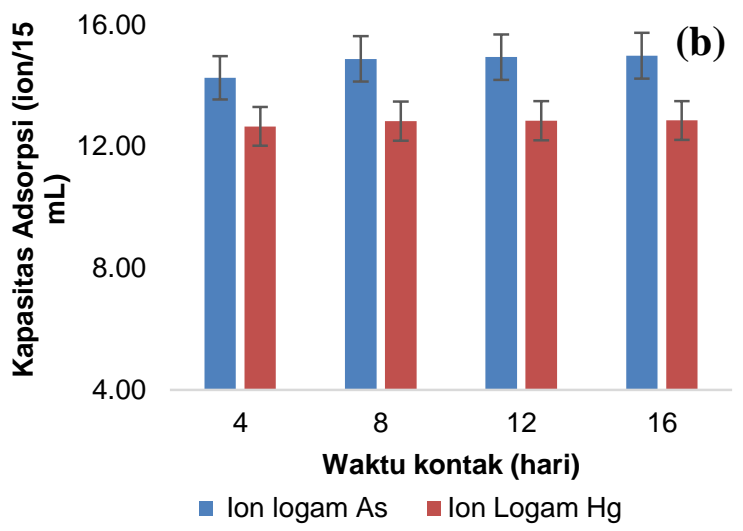

Gambar 3. Kapasitas bioabsorpsi isolat Bl.6 (a) dan isolat Ac.8 (b) terhadap ion $\mathrm{As}^{3+}$ dan $\mathrm{Hg}^{2+}$

Terlihat pada gambar 3.b bahwa kapasitas bioabsorpsi isolat bakteri Bl.6 dan Ac.8 lebih tinggi terhadap ion $\mathrm{As}^{3+}$ dibandingkan terhadap ion $\mathrm{Hg}^{2+}$ (Bibi et al., 2016; Moh et al., 2005). Faktor yang berpengaruh berupa karakteristik isolat yang digunakan, jenis logam berat dan lingkungan interkasi, sebagaimana telah diuraikan di atas. Faktor internal bakteri isolat berupa jumlah sel, spesies isolat, kemampuan adaptasi. Karakteristik ion logam, misalnya jumlah bilangan oksidasi, jari-jari ion, sifat elektronegtivitas, dan faktor lingkungan interaksi. Uraian serapan, daya jerap dan dan

$$
250.00
$$

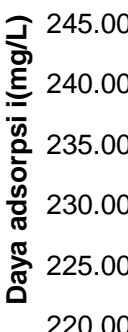

220.00 (a)

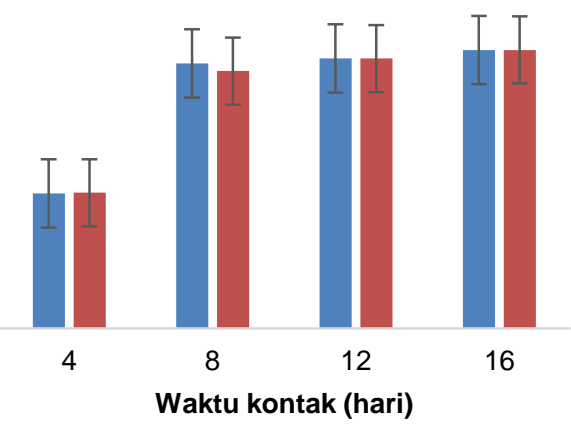

Isolat bakteri BI.6 Isolat bakteri Ac.8 efisiensi bioabsorpsi dipengaruhi oleh sifat dan karateristik yang dimiliki oleh bakteri sebagai adsorben, terutama jenis bakteri, nutrisi, ketersediaan oksigen, jumlah sel yang digunakan dan waktu kontak. Faktor-faktor tersebut sehingga pada penelitian ini selama masa interaksi dilakukan aerasi untuk mensuplai oksigen terhadap bakteri dalam melakukan aktivitasnya yang diharapkan kenerja bioabsorpsi bakteri terhadap logam berat berjalan maksimal (Abdel et al., 2018). Faktor lainnya adalah jenis dan sifat ion logam sebagai kontaminan dan faktor lingkungan atau kondisi interaksi.

$$
214.000
$$

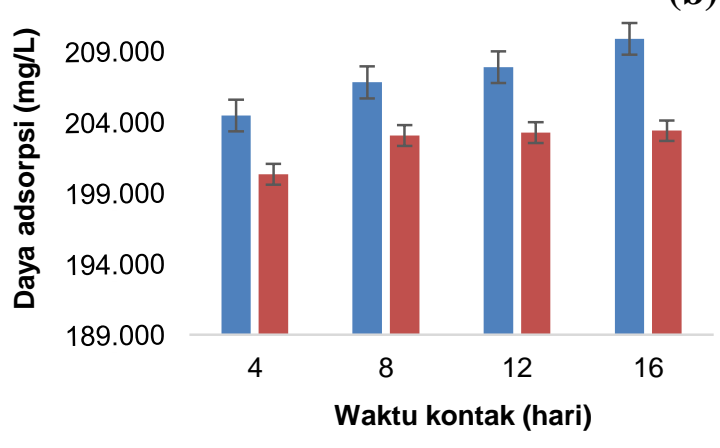

- Isolat bakteri BI.6 - Isolat bakteri Ac.8

Gambar 4. Daya bioabsorpsi isolat BI.6 dan Ac.8 terhadap ion $\mathrm{As}^{3+}$ (a) dan $\mathrm{Hg}^{2+}$ (b). 
Berdasarkan daya serapan, nilai serapan, efisiensi dan kapasitas bioabsorpsi isolat bakteri Bl.6 dan Ac.8 yang hampir semuanya menunjukkan bahwa kinerja bioabsorpsi isolat bakteri jenis Bl.6 simbion spons laut Aulleta Sp dan bakteri Ac.8 simbion spons Callyspongia aerizusa lebih dominan terhadap ion $\mathrm{As}^{3+}$ (Gambar 4.a) dibandingkan terhadap ion $\mathrm{Hg}^{2+}$ (Gambar 4.b). Hasil ini dipengaruhi oleh tiga faktor yakni faktor karakteristik isolat bakteri adsorben, sifat dan jenis ion logam uji sebagai adsorbat dan kondisi lingkungan selama masa interaksi. Kinerja isolat bakteri BI.6 relatif sebanding dengan bakteri Ac.8 dalam bioabsorpsi terhadap ion $\mathrm{As}^{3+}$ dan lebih dominan dalam bioabsorpsi terhadap ion $\mathrm{Hg}^{2+}$, banyak dipengaruhi oleh faktor internal kedua bakteri tersebut, misalnya jumlah sel yang digunakan, $\mathrm{pH}$ dan waktu serta temperatur interaksi antara suspensi bakteri dengan kontaminan logam berat.

\section{KESIMPULAN}

Isolat bakteri Bacillus licheniformis strain ATCC 9789 (BI.6) mikro simbiosis Auletta Sp dan isolat bakteri Acinetobacter calcoaceticus strain PHCDB14 (Ac.8), mikro simbiosis spons Callyspongia aerizusa memiliki kinerja bioabsorpsi terhadap kontaminan uji ion $\mathrm{As}^{3+}$ dan $\mathrm{Hg}^{2+}$. Kapasitas bioabsorpsi bakteri BI.6 terhadap ion $\mathrm{As}^{3+}=14,99$ dan $\mathrm{Hg}^{2+}=13,27$, sedangkan bakteri Ac.8 terhadap $\mathrm{As}^{3+}=14,99$ dan $\mathrm{Hg}^{2+}=12,86$. Kinerja isolat bakteri BI.6 relatif sesuai dengan Ac.8 dalam bioabsorpsi terhadap ion $\mathrm{As}^{3+}$ dan lebih dominan BI.6 dibandingkan Ac.8 terhadap ion $\mathrm{Hg}^{2+}$. Parameter daya bioabsorpsi, serapan ion, efisiensi dan kapasitas bioabsorpsi Bl.6 jauh lebih besar terhadap ion $\mathrm{As}^{3+}$ dibandingkan terhadap ion $\mathrm{Hg}^{2+}$.

\section{UCAPAN TERIMA KASIH}

Penulis mengucapkan terima kasih kepada tenaga laboran di Lab. Biokimia dan Lab. Kimia Analitik Jurusan Kimia FMIPA Unhas. Kepada mahasiswa yang telah bekerja dengan baik menyelesaikan penelitian ini sebagai rangkaian penelitian yang didanai Ristekdikti/BRIN khususnya DRPM dalam skema Penelitian Terapan tahun pertama (2020) dari rencana tiga tahun penelitian (2020-2021) sesuai Surat Keputusan Direktur Riset DRPM Ristekdikti/BRIN No. B/87/E3/RA.00 /2020 dan Nomor Kontrak penelitian LPPM Unifa 25/AI/LPPMUNIFA/IV/2020.

\section{DAFTAR PUSTAKA}

Abdel-Rahman, G. N., Ahmed, M. B. M., \& Marrez, D. A. (2018). Reduction of heavy metals content in contaminated vegetables due to the post-harvest treatments. Egyptian Journal of Chemistry, 61(6), 1031-1037. https://doi.org/10.21608/ej chem.2018.3624.1303

Agarwal, C., \& Bagla, P. . (2013). Biocidal Effects of $\mathrm{Cu}$ (II) and $\mathrm{Ni}$ (II) Complexes of Schipp Base From Coumarin Moeity. Asian Journal of Chemical and Envirimental Research, 6(3), 105-109.

Akinde, S. B., \& Iwuozor, C. C. (2012). Alkane Degradative Potentials of Bacteria Isolated From the Deep Atlantic Ocean of the Gulf of Guinea. Journal of Bioremediation and Biodegradation, 03(01), 1-6. https://doi. org/10.4172/2155-6199.1000135

Bibi, F., Faheem, M., Azhar, E. I., Yasir, M., Alvi, S. A., Kamal, M. A., ... Nasser, M. I. (2016). Bacteria From Marine Sponges: A Source of New Drugs Bacteria From Marine Sponges: A Source of $\mathrm{New}$ Drugs. Current Drug Metabolism, 17(October), $1-6$. https://doi.org/10.2174/1389200217666 1610130906 
de Voogd, N. J. (2007). The mariculture potential of the Indonesian reef-dwelling sponge Callyspongia (Euplacella) biru: Growth, survival and bioactive compounds. Aquaculture. https://doi.org/10.1016/j. aquaculture.2006.09.028

Gebregewergis, A. (2020). Levels of selected metals in white teff grain samples collected from there different areas of Ethiopia by using Microwave Plasma Atomic Emission Spectroscopy (MPAES). International Journal of Novel Research in Physics Chemistry \& Mathematics, 7(1), 13-24.

Hidayah, A. M., Purwanto, \& Soeprobowati, T. R. (2014). Biokonsentrasi Faktor Logam Berat $\mathrm{Pb}, \mathrm{Cd}, \mathrm{Cr}$ dan Cu pada Ikan Nila ( Oreochromis niloticus Linn .) di Karamba Danau Rawa Pening. BIOMA, 16(1), 1-9.

Lajayer, B. A., Khadem, N., Maghsoodi, M. R., \& Ghorbanpour, M. (2019). Phytoextraction of heavy metals from contaminated soil, water, atmosphere using ornamental plants: mechanisms and efficiency improvement strategies. Enironmental Science and Pollution Research, (February). https://doi.org/10.1007/s 11356-01904241-y

Lu, C., Hong, Y., Liu, J., Gao, Y., Ma, Z., Yang, B., ... Waigi, M. G. (2019). A PAHdegrading bacterial community enriched with contaminated agricultural soil and its utility for microbial bioremediation is. Environmental Pollution, 251(Mei), 773782.

https://doi.org/10.1016/j.envpol.2019. 05.044

Mardekawati, L., Burhanuddin, \& Dewantara, I. (2004). The Ability Of Four Variety of Plant In Absorb Mercury Contamination in Tailings, 3(2), 52-60.

Marzuki, I, Sinardi, S., Pratama, I., Chaerul, M., Paserangi, I., Mudyawati, M., \& Asaf, R. (2021). Performance of sea sponges micro symbionts as a biomaterial in biodegradation naphthalene waste of modified. IOP Conference Series: Earth and Environmental Science, 737(1), 012016. https://doi.org/10.1088/17551315/737/1/012016

Marzuki, Ismail. (2018). Eksplorasi Spons Indonesia Seputar Kepulauan Spermonde. (A. Noor, Ed.) (1st ed., Vol.
1). Makassar: Nas Media Pustaka. https://doi.org/10. 17605/OSF.IO/VP369

Marzuki, Ismail. (2020). The Bio-adsorption Pattern Bacteria Symbiont Sponge Marine Against Contaminants Chromium and Manganese In The Waste Modification of Laboratory Scale. Indonesia Chimica Acta, 13(1), 1-9. https://doi.org/http://dx.doi.org/ 10.20956/ica.v13i1.9972

Marzuki, Ismail, Alwi, R. S., Erniati, Mudyawati, Sinardi, \& Iryani, A. S. (2019). Chitosan Performance of Shrimp Shells in The Biosorption Ion Metal of Cadmium, Lead and Nickel Based on Variations $\mathrm{Ph}$ Interaction. Atlantik Press, 165(1), 6-11. https://doi.org/10.2991/icmeme18.2019 .2

Marzuki, Ismail, Ashari, M. I., Marsuki, A. A., \& Angela, A. (2019). Aplikasi Mikrosimbions Spons Laut Sebagai Biomaterial Pereduksi Toksisitas Logam Berat Kromium. Al-Kimia, 7(1), 67-75. https://doi.org/10.242 52/alkimia.v7i1.7388

Marzuki, Ismail, Daris, L., Yunus, S., \& Riana, A. D. (2020). Selection and characterization of potential bacteria for polycyclic aromatic biodegradation of hydrocarbons in sea sponges from Spermonde Islands, Indonesia. AACL Bioflux, 13(6), 3493-3506.

Marzuki, Ismail, Kamaruddin, M., \& Ahmad, R. (2021). Identification of marine spongessymbiotic bacteria and their application in degrading polycyclic aromatic hydrocarbons. Biodiversitas, 22(3), 1481-1488.

https://doi.org/10.13057/biodiv/d2 20352

Marzuki, Ismail, Noor, A., Nafie, N. La, \& Djide, M. N. (2015). Moleculer Characterization Of Gene 16S rRNA Microsymbionts In Sponge At Melawai Beach, East Kalimantan. Marina Chimica Acta, 16(1), 38-46.

Marzuki, Ismail, Noor, A., Nafie, N. La, \& Djide, M. N. (2016). Morphological and phenotype analysis of microsymbiont and biomass marine sponge from melawai beach, Balikpapan, east kalimantan. International Journal Marina Chimic Acta, 17(1), 8-15.

Marzuki, Ismail, Sinardi, Asmeati, \& Yunus, S. (2019). Aplikasi Mikrosimbion spons laut sebagai material dalam metode bioremediasi toksisitas logam berat. In 
Prosiding Seminar Nasional Penelitian \& Pengabdian Kepada Masyaraka (Vol. 2019, pp. 1-6).

Medic, A., Ljesevic, M., Inui, H., Stojanovic, K., Karadzic, I., Be`skoski, V., \& Koji, I. (2020). Efficient biodegradation of petroleum $n$-alkanes and polycyclic aromatic hydrocarbons by polyextremophilic Pseudomonas aeruginosa san ai with multidegradative capacity. Royal Society of Chemistry Advances, 10(April), 14060-14070. https://doi.org/10.1039/C9RA 10371F

Melawaty, L., Noor, A., Harlim, T., \& de Voogd, N. (2014). Essential metal $Z n$ in sponge Callyspongia aerizusa from Spermonde Archipelago. Advances in Biological Chemistry, 04(01), 86-90. https://doi.org/10.4236/abc.2014.41012

Moh, P., Zubair, A., Maricar, I., \& Ides, V. (2005). Fitoremediasi Tanah Tercemar Logam $\mathrm{Cr}$ dengan Tumbuhan Akar Wangi pada Tanah Berkompos, 1-24.

Mostafidi, M., Shirkhan, F., Zahedi, M. T., Ziarati, P., \& Hochwimmer, B. (2019). Risk Assessment of the Heavy Metals Contents in Ready-to-eat Vegetables in Distributed Brands at the Supply Level of Sales Centers in Tehran, Iran. ResearchGate On Line, (February 2020), $1-12$. https://doi.org/10.35932/ijcsrem.v2i1.16

Muszyńska, E., Labudda, M., Kamińska, I., Górecka, M., \& Bederska-Błaszczyk, M. (2019). Evaluation of heavy metalinduced responses in Silene vulgaris ecotypes. Protoplasma, (May). https://doi.org/https://

doi.org/10.1007/s00709-019-01384-0

Novitriani, K., \& Kusmiati, M. (2015). Efektivitas Eceng Gondok ((Eichormia crassipes) Dalam Penyerapan Logam Berat Timbal $(\mathrm{Pb})$. Jurnal Kesehatan Bakti Tunas Husada: Jurnal IImu-IImu Keperawatan, Analis Kesehatan Dan Farmasi, 9(1), 97. https://doi.org/10.36465/jkbth.v9i1.100

Orani, A. M., Barats, A., Vassileva, E., \& Thomas, O. P. (2018). Marine sponges as a powerful tool for trace elements biomonitoring studies in coastal environment. Marine Pollution Bulletin, 131(April),

633-645.

https://doi.org/10.10

16/j.marpolbul.2018.04.073

Putri, Y. D., Holik, H. A., Musfiroh, I., \& Aryanti, A. D. (2014). Utilization of Ponteridaceae as Phytoremediation Agent in Chrome Waste Treatment. Indonesian Journal of Pharmaceutical Science and Technology, 1(1), 20-25. https://doi.org/10.15416/ijpst.v1i1.7510

Siahaya, N., Noor, A., Sukamto, N., \& de Voogd, N. (2013). A preliminary effort to assign sponge (\&lt;i\&gt;Callispongia sp\&lt;/i\&gt;) as trace metal biomonitor for $\mathrm{Pb}, \mathrm{Cd}, \mathrm{Zn}$, and $\mathrm{Cr}$, an environmental perspective in Hative gulf waters Ambon. Advances in Biological Chemistry, 03(06), 549-552. https://doi.org/10.4236/abc.2013.36062

Sobrinho Nelson Moura Brasil do Amaral, De, A. A. F. M., Abreu, L. E. S., \& Zonta, E. (2020). Metals Phytoextraction by Cordia africana from Soils Contaminated with Oil Drilling Waste. Floresta e.Ambiente, 27(1), 1-8.

Supriyantini, E., Azizah, R., Nuraini, T., \& Dewi, P. (2017). Daya Serap Mangrove Rhizophora sp . Terhadap Logam Berat Timbal ( $\mathrm{Pb}$ ) Di Perairan Mangrove Park , Pekalongan. Jurnal Kelautan Tropis, 20(1), 16-24.

Suryati, T., \& Priyanto, B. (2003). Eliminasi Logam Berat Kadmium Dalam Air Limbah Menggunakan Tanaman Air. ..J.Tek.Ling,P3TL-BPPT, 4(3), 143-147.

Venkateswara Rao, J., Srikanth, K., Pallela, R., \& Gnaneshwar Rao, T. (2009). The use of marine sponge, Haliclona tenuiramosa as bioindicator to monitor heavy metal pollution in the coasts of Gulf of Mannar, India. Environmental Monitoring and Assessment.

https://doi.org/10.1007/s106 61-0080497-x

Wibowo, N., Nurcahyo, R., \& Gabriel, D. S. (2019). Sponge Iron Plant Feasibility Studi in Kalimantan, Indonesia. ARPN Journal of Engineering and Applied Sciences, 14(23), 4013-4020. 